Journal of Engineering and Applied Sciences 14 (Special Issue 5): 9177-9184, 2019

ISSN: 1816-949X

(C) Medwell Journals, 2019

\title{
Preparation and Characterization of Silver Oxide Nanoparticles (AGNPS) and Evaluation the Ratios of Oxides
}

\author{
${ }^{1}$ Firas H. Abdulrazzak, ${ }^{2}$ Ahmed M. Abbas, ${ }^{1}$ Mostefe Khalid Mohammed, ${ }^{2}$ Israa Mohammed Radhi, \\ ${ }^{1}$ Ahmed E. Abdullatif, ${ }^{2}$ Hamsa M. Yaseen, ${ }^{3}$ Duah Ayad Yas and ${ }^{4}$ Ayad F. Alkaim \\ ${ }^{1}$ Department of Chemistry, College of Education for Pure Science, University of Diyala, Baqubah, Iraq \\ ${ }^{2}$ Department of Chemistry, College of Education for Pure Science, University of Baghdad, \\ Baghdad, Iraq \\ ${ }^{3}$ Technical Institute, Baquba, Iraq \\ ${ }^{4}$ Department of Chemistry, College of Science for Women, University of Babylon, Hilla, Iraq \\ firas_habeb2000@yahoo.com
}

\begin{abstract}
Silver nanoparticles (AGNP) were prepared as a mixture of $\mathrm{AgO}, \mathrm{Ag}_{2} \mathrm{O}$ and $\mathrm{Ag}$ from silver nitrate and hydrogen peroxide at room temperature in dark. The process of synthesis includes changing the sequence of addition for $\mathrm{AgNO}_{3}$ and $\mathrm{H}_{2} \mathrm{O}_{2}$ in addition to change the concentration of $\mathrm{H}_{2} \mathrm{O}_{2}$. The structural morphology and optical properties of silver nanoparticles (AGNPS) were characterized by X-Ray Diffraction (XRD), Atomic Force Microscopy (AFM), UV-visible absorbance and Fourier-Transform Infrared Spectroscopy (FTIR). The results showed that the change in routes of addition for materials causing produces the change in the ratios of $\mathrm{Ag}$ species. The highest value for $\mathrm{Ag}$ nanoparticles was shown for $\mathrm{Ag}_{2}$ when produces $31.25 \%$ while $\mathrm{Ag}_{3}$ consist $71.10 \%$ of $\mathrm{AgO}$. The antibacterial activity for the synthesized AGNPS were shown variances when tested with bacterial Acinetobacter baumannii which shows maximum activities with AG3.
\end{abstract}

Key words: $\mathrm{AGNP}, \mathrm{H}_{2} \mathrm{O}_{2}$, Acinetobacter baumannii, $\mathrm{XRD}, \mathrm{AFM}, \mathrm{AgO}$

\section{INTRODUCTION}

Nanoparticles are mono, di or tri dimensions with 1-100 $\mathrm{nm}$ in the size (Hasan, 2015) when emerging with science forming nanoscience. The pattern which is owned by nanoparticles can be related to rare physical and chemical properties as compared to their bulk materials. Mostly, the specific properties with electronic structures cause large reactive surface area and quantum size (Hodes, 2007). The amazing properties encourage to use nanoparticles in huge fields such as electronics, photochemical, biomedicine, polishing and coatings (Saez and Mason, 2009). Jawaad et al. (2014) reported that AGNPS is commonly used to kill microbe by abilities to interact with different conditions which variance with the morphology of nanoparticles such spherical, cubic and triangular prism. These types can be prepared use organic, inorganic or hybrid of organic and inorganic materials by thermal or vapor decomposition (Henglein, 1993; Sopousek et al., 2012), microemulsions or chemical reduction methods (Merza et al., 2012). The large surface area to volume ratio for metallic enhances bactericidal properties when showing resistance against the growing microbial and success to the development of resistant strains (Gong et al., 2007). Mostly, the silver nanoparticles were synthesis in aqueous solution by reduction of $\mathrm{Ag}^{+}$to forming colloidal of $\mathrm{Ag}^{0}$ with nanometers in diameter. The colloidal of $\mathrm{Ag}^{0}$ which followed by produce agglomeration of $\mathrm{Ag}$ clusters. The first indicator that proves the forming nanoparticles represent by an intense band in the $380-400 \mathrm{~nm}$ for yellow color in the absorption spectrum. Hussain et al. (2011) used aniline as reductant and oxidant, respectively, to the growth of silver nanocrystals from silver nitrate. The interparticle interaction of aniline with Ag-nanocrystals on the surface and electrostatic interactions due exist lone-pairs electrons of amine groups with positive surface of Ag-nanoparticles enhance forming nano size. Silva et al. (2013) used $\mathrm{H}_{2} \mathrm{O}_{2}$ between 0.4 and $0.6 \%$ $(\mathrm{V} / \mathrm{V})$ which represent ideal value to produce AGNPS. Dimitrijevic et al. (2013) synthesized spherical nanoparticles in large quantity by using a modified method of hydrolytic decomposition of silver complexes with amino types in ethanol aqueous solution. Awwad and Salem (2012) used green chemistry to synthesized $\mathrm{Ag}$ nanoparticles from deferent natural sources such plant which produces inorganic nanoparticles by photo or electro chemical reduction and

Corresponding Author: Firas H. Abdulrazzak, Department of Chemistry, College of Education for Pure Science, 
heat evaporation methods. Jyoti et al. (2016) used aqueous leaves extract of Urica dioica for synthesize of AGNPS. Many efforts were done to synthesis $\mathrm{Ag}$ as nanoparticles AGNPS which appears mostly with different ratios of oxidation for $\mathrm{Ag}$. In this research, $\mathrm{Ag}$ nanoparticles were prepared as a mixture of $\mathrm{Ag}^{0}, \mathrm{Ag}^{+1}$ and $\mathrm{Ag}^{+2}$ by using three ways the first two ways include the same conditions with changing the sequence of additions. The third ways were the same conditions of the first only the change was the double in the concentration of $\mathrm{H}_{2} \mathrm{O}_{2}$. Simple and easy reaction was done to reach for best ratios of AGNPS. All the samples were characterized by X-ray diffraction, Atomic Force Microscopy (AFM), optical property and Fourier-Transform Infrared Spectroscopy (FTIR).

\section{MATERIALS AND METHODS}

Experimental: Silver nitrate $\left(\mathrm{AgNO}_{3}\right)$ salt was supplied by Sigma-Aldrich. The hydrogen peroxide $\mathrm{H}_{2} \mathrm{O}_{2}$ was purchase from Barcelona, Spain in 30\% weight, all materials were used without any purification. Three samples were prepared AG3, AG2 and AG3 in dark. The first sample AG3 was prepared by dissolved $0.5 \mathrm{~g}$ of $\mathrm{AgNO}_{3}$ in $10 \mathrm{~mL}$ of distilled water which drop wise to $20 \mathrm{~mL}$ hydrogen peroxide $15 \%(\mathrm{~V} / \mathrm{V} \%)$ at $10^{\circ} \mathrm{C}$ by using separation funnel as shown in Fig. 1a. After complete additions $\mathrm{AgNO}_{3}$ solution, the mixture kept in dark for $5 \mathrm{~h}$ at room temperature. The precipitation was removed from the solution and drying at $7^{\circ} \mathrm{C}$ at $\mathrm{N}_{2}$ gas atmosphere for $10 \mathrm{~h}$. The second sample $\mathrm{AG} 2$ was prepared by dropped $\mathrm{H}_{2} \mathrm{O}_{2}$ onto $\mathrm{AgNO}_{3}$ solution which is opposite the ways of forming AG3. The third sample AG3 was prepared as $\mathrm{AG} 3$ with double concentration of $\mathrm{H}_{2} \mathrm{O}_{2}$ to $30 \%$.
Characterizations: The elemental composition of as prepared samples was determined by X-Ray Diffraction (XRD) patterns with a (Riga Rotalflex-RU-200B) using $\mathrm{Cu}$ $\mathrm{K} \alpha$ radiation (wavelength $0.15405 \mathrm{~nm}$ ) at room temperature. The $2 \theta$ angular regions between 10 and $80^{\circ}$ were explored at a scan rate of $5^{\circ} / \mathrm{min}$. For all the XRD analysis, the resolution in the $2 \theta$ scans was kept at $0.02^{\circ}$. The optical properties of the samples were examined by using a UV-Visible spectrophotometer at the normal incidence of light in the wavelength range of $200-1100 \mathrm{~nm}$. Fourier Transfer Infrared (FT-IR) spectra were measured on a Shimadzu IRAffinity-1 FTIR spectrophotometer with a resolution of $4 \mathrm{~cm}^{-1}$. The spectrum was scanned from $\left(600-4000 \mathrm{~cm}^{-1}\right)$. Figure 2, refer to X-Ray Diffraction (XRD) pattern of three samples which include four types of $\mathrm{AGNP}$ such $\mathrm{Ag}, \mathrm{AgO}$ and $\mathrm{Ag}_{2} \mathrm{O}$. Mostly the common crystalline planes having cubic orientations (Hofmeister et al., 2005). The three phases of silver which forming are two oxides $\mathrm{Ag}_{2} \mathrm{O}$ and $\mathrm{AgO}$ with $\mathrm{Ag}$ nanoparticles. The three samples AG1-AG3 show the variant in the ratios of three materials this could be attributed to the conditions of precipitations (Nwanya et al., 2013). The compare between $\mathrm{AgNO}_{3}$ and the three samples can be seen real change in crystallography. The AG3 shows many noises, mostly refer to unconverted $\mathrm{AgNO}_{3}$ for AGNP and while AG2 and AG3 Distinguished by new structures with new crystallography.

The same results can be seen in Fig. 3 of AFM images for three colloid samples AG1-AG3 when exhibiting different size distributions. The image for AG3 shows many irregular structures with many agglomerates when reaching to $120 \mathrm{~nm}$ as shown in Table 1 . The reason

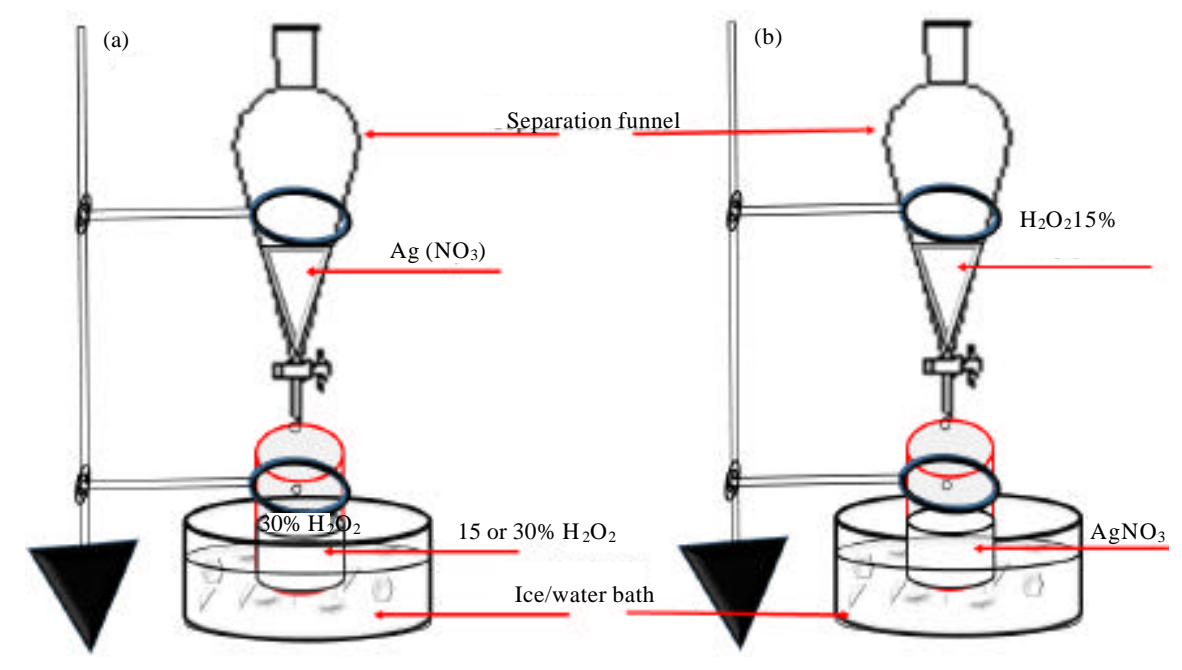

Fig. 1: Schematic diagram for synthesis: a) AG1, AG3 and b)Ag 


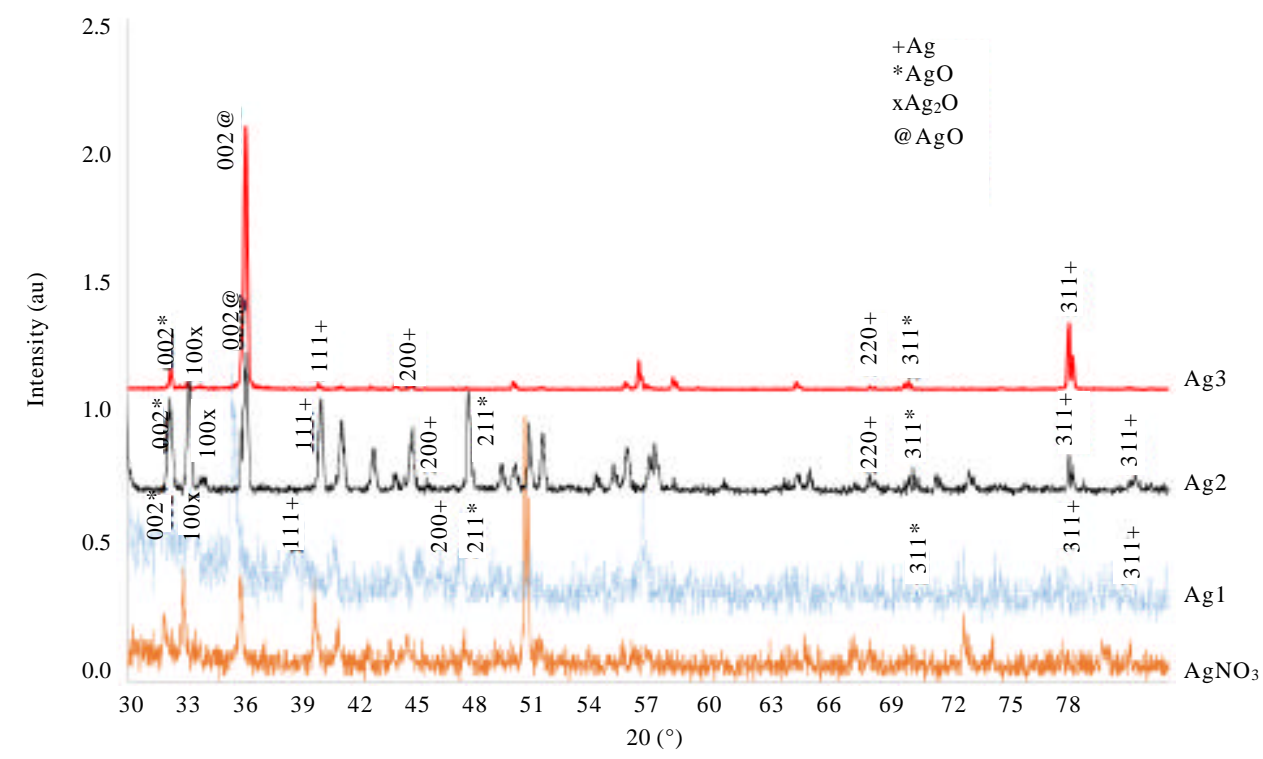

Fig. 2: The XRD pattern of pristine $\mathrm{AgNO}_{3}$ and synthesized: a) AG1; b) AG2 and c) AG3
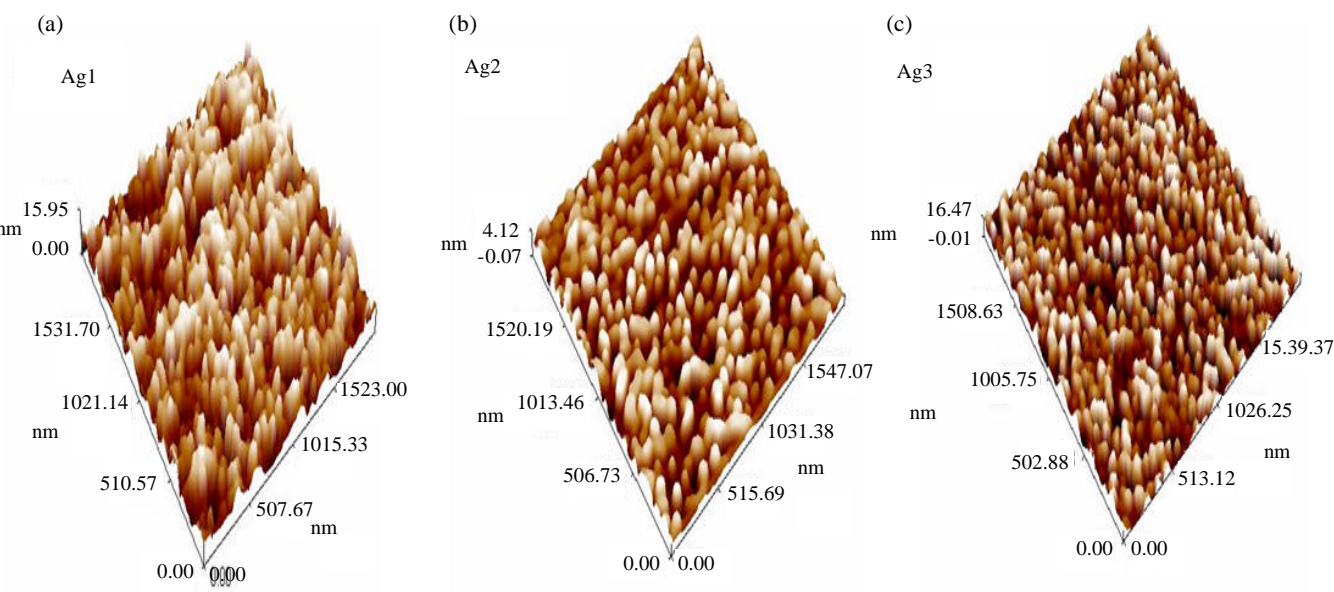

Fig. 3: Three dimensions AFM surface images of three synthesized samples: a) AG1; b) AG2 and c) AG3

behind large particle size can be related to addition $\mathrm{AgNO}_{3}$ for peroxide medium with low ratios $\mathrm{H}_{2} \mathrm{O}_{2}$ which cause many aggregations prevent $\mathrm{AgNO}_{3}$ to react with $\mathrm{H}_{2} \mathrm{O}_{2}$. The second sample AG2 shows more crystallinity with more regular structure as compare with $\mathrm{AgNO}_{3}$ and AG3. The behavior of AG2 refers to slowly precipitation for $\mathrm{AgNO}_{3}$ with drop wise $\mathrm{H}_{2} \mathrm{O}_{2}$ causing growth different ratios of $\mathrm{Ag}^{0}, \mathrm{Ag}^{+1}$ and $\mathrm{Ag}^{+2}$. According to UV-Vis spectra (Fig. 2), the AGNP formed present distinct size, since, the position of the main band is related to the area of the formed particles.

AFM image for the three samples was reported in Fig. 3 with a statistical calculation of AFM images were
Table 1: Relative intensity and percentage of $\mathrm{Ag}$ types nanoparticles in three samples

\begin{tabular}{lcccccccc}
\hline & \multicolumn{3}{c}{ Relative intensity (au) } & \multicolumn{4}{l}{ Percent the type of $\mathrm{Ag}(\%)$} \\
& $-\mathrm{Ag}^{+}$ & $\mathrm{AgO}^{*}$ & $\mathrm{Ag}_{2} \mathrm{O}$ & $\mathrm{AgO}^{\Theta}$ & $\% \mathrm{Ag}^{+}$ & $\mathrm{AgO}^{*} \%$ & $\mathrm{Ag}_{2} \mathrm{O}^{\mathrm{X}_{0}} \%$ & $\% \mathrm{AgO}^{\Theta}$ \\
\hline $\mathrm{Ag} 3$ & 2.5 & 2.8 & 1.3 & 4.6 & 22.32 & 25.00 & 11.60 & 41.07 \\
$\mathrm{Ag} 2$ & 4.0 & 4.0 & 2.0 & 2.8 & 31.25 & 31.25 & 15.62 & 21.87 \\
$\mathrm{Ag3}$ & 1.5 & 0.4 & 0.1 & 4.9 & 21.73 & 05.79 & 01.44 & 71.10 \\
\hline
\end{tabular}

performed using specially designed image processing software in Fig. 4 which listed in Table 1. From the AFM images, we can see many big clusters of nanoparticles appears as aggregates forming during the deposition for AG1 and AG2 while AG3 shows more ravens with less 

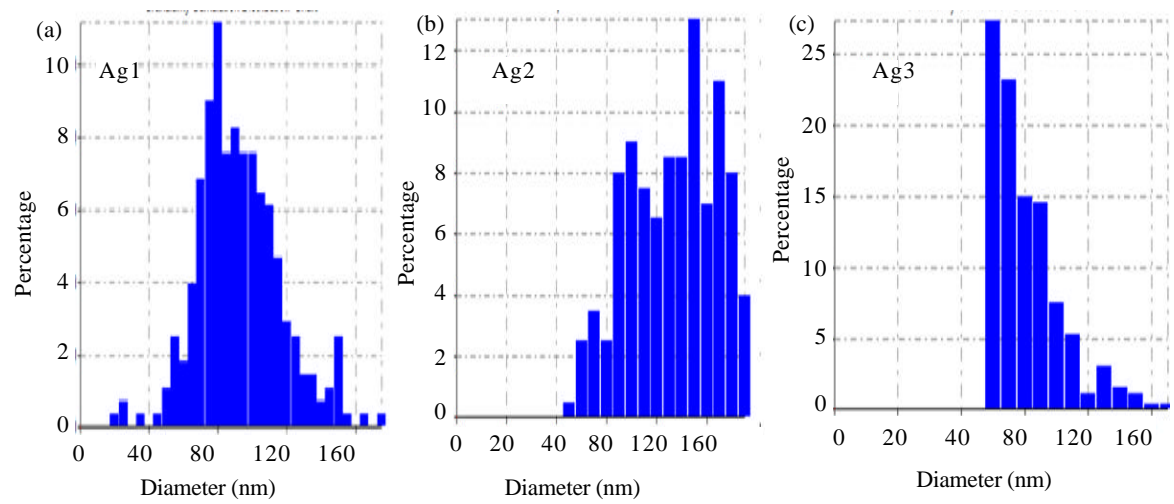

Fig. 4: Sckematic digrame for the percent of diameter for three samples: a) AG1; b) AG2 and c) AG3

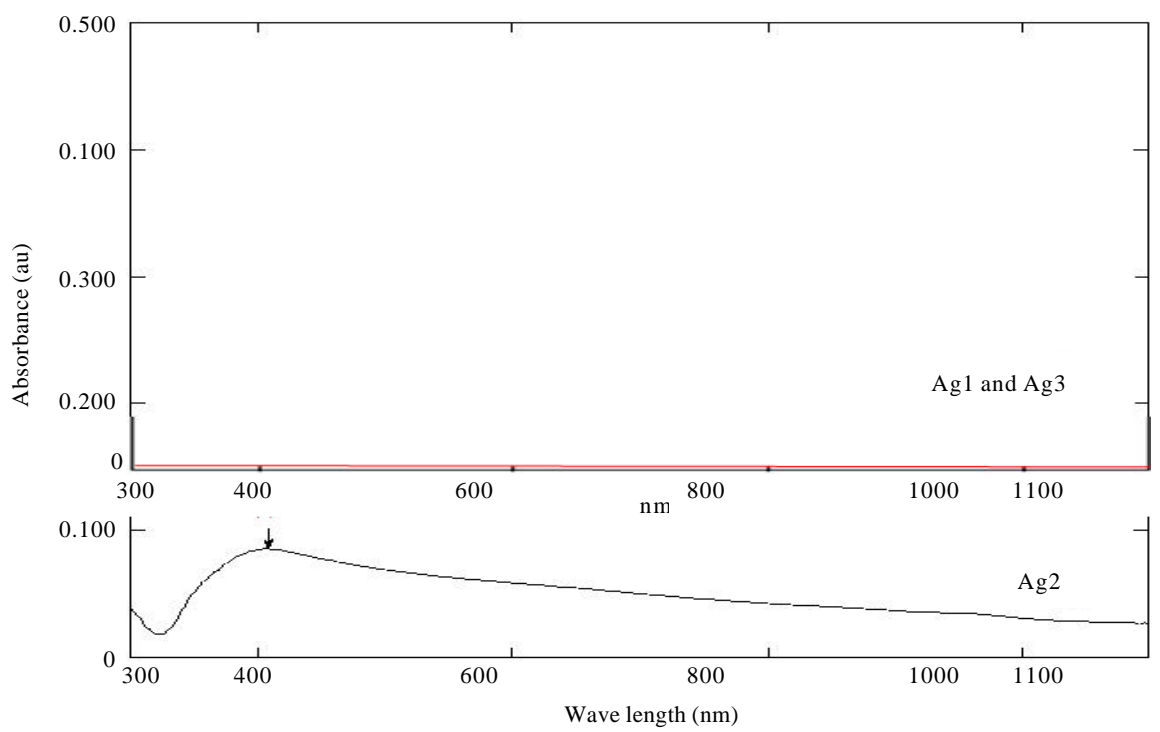

Fig. 5: Normalized UV-Vis spectra for three samples AG1, AG2 and AG3

Table 2: The value of average and mode diameters for the nanoparticles in the samples

\begin{tabular}{lcc}
\hline Samples & Average diameter $(\mathrm{nm})$ & Mode diameter $(\mathrm{nm})$ \\
\hline $\mathrm{Ag3}$ & 90.21 & 120 \\
$\mathrm{Ag} 2$ & 83.95 & 105 \\
$\mathrm{Ag3}$ & 57.90 & 70 \\
\hline
\end{tabular}

value in size of clusters. The results were listed in Table 2 which shows variants in an average diameter in three samples which refer to regular precipitation in sample 3 .

The optical property of synthesized silver nanoparticles between 300 and $1100 \mathrm{~nm}$ are plotted in Fig. 5. Sample AG2 shows one absorption peak ranging between $350-950 \mathrm{~nm}$ refer to high ratios of $\mathrm{Ag}$ nanoparticles (Hussain et al., 2011) as compared with AG3 and AG3 samples which are sensitive to synthesis condition.
FTIR analysis in Fig. 6 was performed at room temperature in the range of $600-4000 \mathrm{~cm}^{-1}$. The peak at 1550 and $1506 \mathrm{~cm}^{-1}$ was concluded to be Nitrate from $\mathrm{AgNO}_{3}$ which is starting metal precursor (Muzamil et al., 2014). This peak was reduced for the samples after treatment with $\mathrm{H}_{2} \mathrm{O}_{2}$. Hydroxyl group shows a broad band at $3351 \mathrm{~cm}^{-1}$ due to bounded stretching and a weak peak at $1637 \mathrm{~cm}^{-1}$ for bending vibrations due to hydrogen peroxide which variant with conditions of oxidation $\mathrm{AgNO}_{3}$ (Mohammadi and Ranjbar, 2017). Mostly, the band appeared at $742 \mathrm{~cm}^{-1}$ was assigned to the deformation vibration of $\mathrm{AgO}$ (Kumar and Rani, 2013) which disappear with $\mathrm{AgNO}_{3}$ while with AG1-AG3 show clear. The second beaks Singho et al. (2012) refer to $\mathrm{AgO}$ stretching at $1635 \mathrm{~cm}^{-1}$ when more pronounced in $\mathrm{AG} 2$ and $\mathrm{AG} 3$ and did not appear in $\mathrm{Ag} 3$ and $\mathrm{AgNO}_{3}$. 
J J. Eng. Applied Sci., 14 (Special Issue 5): 9177-9184, 2019
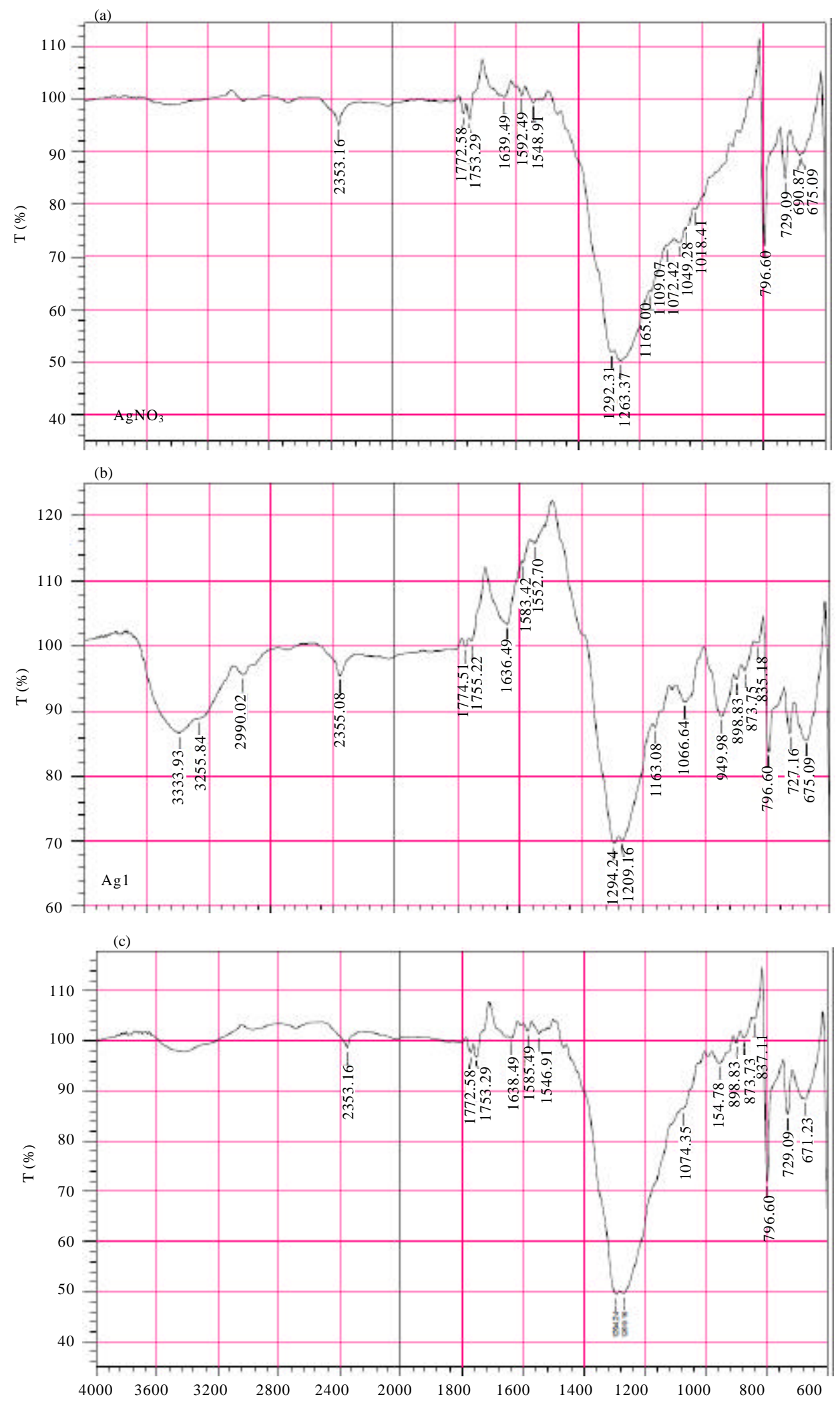

Fig. 6: Continue 


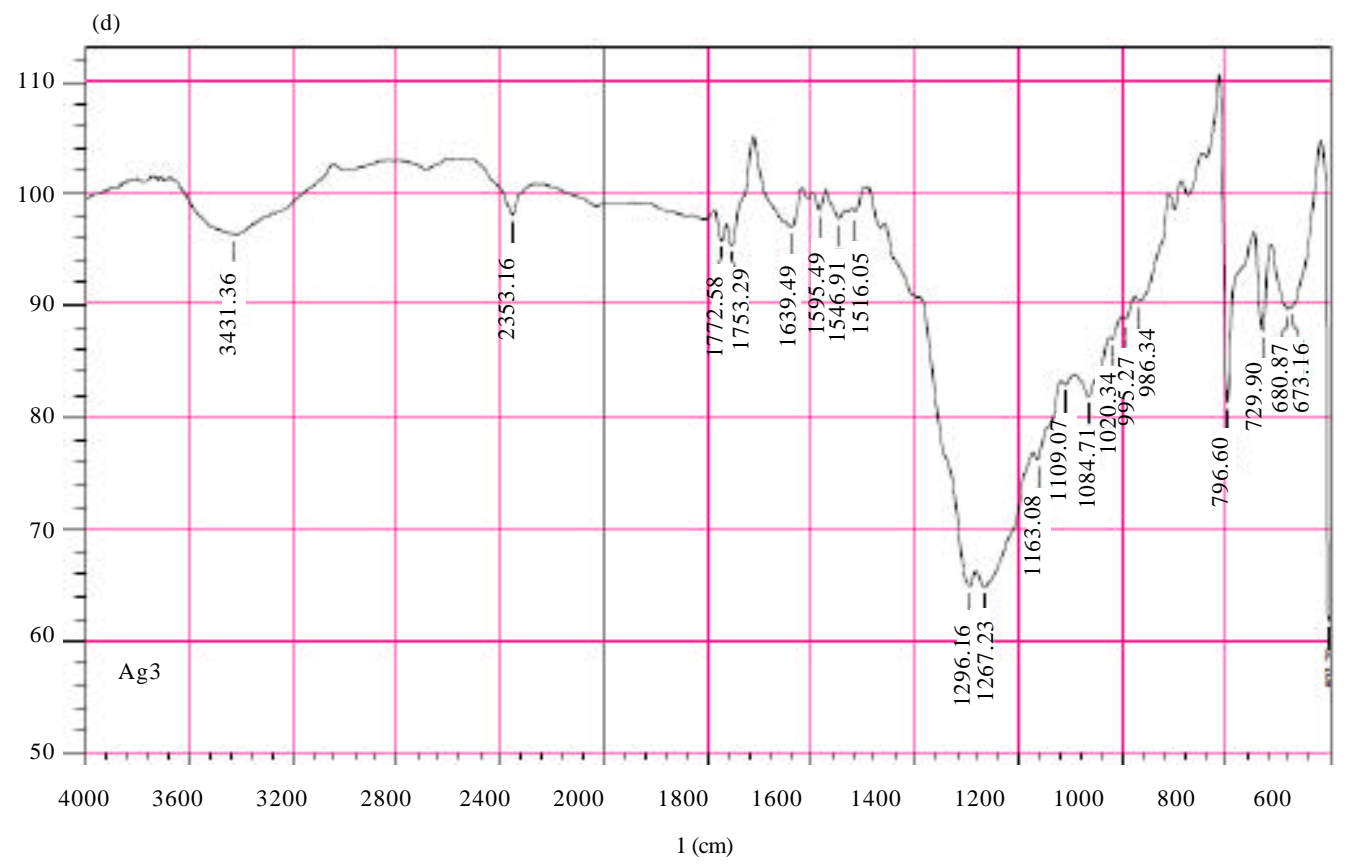

Fig. 6: FTIR spectra of: a) $\mathrm{AgNO}_{3}$; b) $\mathrm{AG} 1$; c) $\mathrm{AG} 2$ and d) $\mathrm{AG} 3$ from $4000-600 \mathrm{~cm}^{-1}$ wavelength

The XRD pattern in Fig. 2, of the three samples at different ways of addition $\mathrm{H}_{2} \mathrm{O}_{2}$ shows crystalline nature with cubic orientations (Hofmeister et al., 2005). $\mathrm{Ag}_{2} \mathrm{O}$ and $\mathrm{AgO}$ are the dominant oxides present with $\mathrm{Ag}^{+}$ nanoparticles at lower deposition time. It is seen that as the strategy of addition $\mathrm{H}_{2} \mathrm{O}_{2}$ change the ratios of nanoparticles $\mathrm{AgO}, \mathrm{Ag}_{2} \mathrm{O}$ and $\mathrm{Ag}$. This could be related to the reaction of $\mathrm{Ag}^{+}$with different free radicals species and anions in the solution as shown in suppose equations:

$$
\begin{aligned}
& \mathrm{H}_{2} \mathrm{O}_{2} \mathrm{HO}_{2}^{-}+\mathrm{H}^{+} \\
& \mathrm{HO}_{2}^{-} \mathrm{HO}+\mathrm{O}^{0} \\
& \mathrm{H}_{2} \mathrm{O}_{2}+\mathrm{HO}_{2}^{-} \mathrm{H}_{2} \mathrm{O}+\mathrm{HO}^{0}+\mathrm{O}_{2}^{-} \\
& 6 \mathrm{Ag}^{+}+\left(2 \mathrm{HO}_{2}^{-} \text {and } \mathrm{O}_{2}^{-} \cdot\right) \rightarrow \\
& \mathrm{Ag}+\mathrm{AgO}+2 \mathrm{Ag}_{2} \mathrm{O}+\mathrm{O}_{2}+\mathrm{H}_{2} \mathrm{O}
\end{aligned}
$$

The first reactive species produce from $\mathrm{H}_{2} \mathrm{O}_{2}$ was $\mathrm{HO}_{2}$. due to unstable and easily produces strong oxidizing agent which represents by $\mathrm{HO}$. As shown in the mechanism three species: $\mathrm{O}^{0}, \mathrm{HO}^{\circ}$ and $\mathrm{O}_{2} \cdot$ that responsible to produces AGNP with variance in the state. The ratios and types of AGNP depend on the concentration $\mathrm{H}_{2} \mathrm{O}_{2} \backslash \mathrm{AgNO}_{3}$ and the nature of species that react with dissolved $\mathrm{Ag}^{+}$particles. It is seen that when $\mathrm{AgNO}_{3}$ was dropped into $\mathrm{H}_{2} \mathrm{O}_{2}$, the $\mathrm{AgO}$ becomes the dominating AGNP while opposite addition enhances forming $\mathrm{Ag}$ more than another species of AGNP. This may be attributed to the reaction of $\mathrm{Ag}^{+1}$ or $\mathrm{Ag}^{+2}$ with $\mathrm{OH}$ as free radicals or anions and the reaction of forming $\mathrm{Ag}$ with $\mathrm{OH}^{-}$at peroxide media. This behavior became more pronounced when the concentration of hydrogen peroxide double which causes high ratios of $\mathrm{AgO}$ and $\mathrm{Ag}_{2} \mathrm{O}$ as compare with $\mathrm{Ag}$.

\section{RESULTS AND DISCUSSION}

Antibacterial activity: The antibacterial activity of silver compounds were tested by bacterial Acinetobacter baumannii to assess the susceptibility activity with using disc diffusion method. The concentration of pristine $\mathrm{AgNO}_{3}$ and synthesized AGNPs were $(1 \mathrm{mg} / \mathrm{mL})$ in aqueous solution which loaded $100 \mu \mathrm{L}$ at $37^{\circ} \mathrm{C}$ for $24 \mathrm{~h}$ as shown in Fig. 7a. The activities were evaluated by measuring the diameter of inhibition zones in micro meter which represented in schemes in Fig. 7b.

The antimicrobial efficacy of silver compound $\mathrm{Ag} 1$ and $\mathrm{AG} 2$ were more than $\mathrm{AG} 3$ and pristine $\mathrm{AgNO}_{3}$. The activity can be related to the surface area (Jyoti et al., 2016; Guzman et al., 2008) when increase the active site that attach to the surface of the cell membrane causing disturb the permeability. The binding of the particles to the bacteria depends on the surface area with active sites which is available for interaction, thus, small particles available for interaction with give more bactericidal effect than the large particle. 
Fig. 7: a) Acinetobacter Baumannii zone of inhibition around silver nanoparticle compounds ( $\left.\mathrm{AgNO}_{3}, \mathrm{AG} 1, \mathrm{AG} 2, \mathrm{AG} 3\right)$ impregnated disk and b) schemes of activity for the synthesized materials

\section{CONCLUSION}

The Ag nanoparticles have been prepared by treatment $\mathrm{AgNO}_{3}$ with $\mathrm{H}_{2} \mathrm{O}_{2}$ which causing forming AGNP as a mixture of pristine $\mathrm{Ag}$ and $\mathrm{Ag}$ oxide. Deposition of silver was carried out with different ratios of species due to change the strategy of additions and concentration of $\mathrm{H}_{2} \mathrm{O}_{2}$. XRD analysis showed the converted in crystallography of $\mathrm{AgNO}_{3}$ to the new structure which mostly consisted of AGNP with three strictures $\mathrm{AgO}$, $\mathrm{Ag}_{2} \mathrm{O}$ and $\mathrm{Ag}$. AFM analysis showed that the routes of adding hydrogen peroxide to silver nitrate causing variant in the structure of crystals. The conditions of preparations effect directly with the particles size and active site which causing variance in activities with Acinetobacter baumannii.

\section{REFERENCES}

Awwad, A.M. and N.M. Salem, 2012. Green synthesis of silver nanoparticles by mulberry leaves extract. Nanosci. Nanotechnol., 2: 125-128.

Dimitrijevic, R., O. Cvetkovic, Z. Miodragovic, M. Simic and D. Manojlovic et al., 2013. SEM/EDX and XRD characterization of silver nanocrystalline thin film prepared from organometallic solution precursor. J. Min. Metall. B. Metall., 49: 91-95.

Gong, P., H. Li, X. He, K. Wang and J. Hu et al., 2007. Preparation and antibacterial activity of $\mathrm{Fe}_{3} \mathrm{O}_{4} \mathrm{Ag}$ nanoparticles. Nanotechnology, 18: 604-611.

Guzman, M.G., J. Dille and S. Godet, 2008. Synthesis of silver nanoparticles by chemical reduction method and their antibacterial activity. Intl. Scholarly Sci. Res. Innovation, 2: 91-98.
Hasan, S., 2015. A review on nanoparticles: Their synthesis and types. Res. J. Recent Sci., 4: 9-11.

Henglein, A., 1993. Physicochemical properties of small metal particles in solution: Microelectrode reactions, chemisorption, composite metal particles and the atom-to-metal transition. J. Phys. Chem., 97: $5457-5471$.

Hodes, G., 2007. When small is different: Some recent advances in concepts and applications of nanoscale phenomena. Adv. Mater., 19: 639-655.

Hofmeister, H., G.L. Tan and M. Dubiel, 2005. Shape and internal structure of silver nanoparticles embedded in glass. J. Mater. Res., 20: 1551-1562.

Hussain, J.I., S. Kumar, A.A. Hashmi and Z. Khan, 2011. Silver nanoparticles: Preparation, characterization and kinetics. Adv. Mat. Lett., 2: 188-194.

Jawaad, R.S., K.F. Sultan and A.H. Al-Hamdani, 2014. Synthesis of silver nanoparticles. ARPN. J. Eng. Appl. Sci., 9: 586-592.

Jyoti, K., M. Baunthiyal and A. Singh, 2016. Characterization of silver nanoparticles synthesized using Urtica dioica Linn. leaves and their synergistic effects with antibiotics. J. Radiat. Res. Applied Sci., 9: 217-227.

Kumar, H. and R. Rani, 2013. Structural characterization of silver nanoparticles synthesized by micro emulsion route. Intl. J. Eng. Innovative Technol., 3: 344-348.

Merza, K.S., H.D. Al-Attabi, Z.M. Abbas and H.A. Yusr, 2012. Comparative study on methods for preparation of gold nanoparticles. Green Sustainable Chem., 2: 26-28.

Mohammadi, K. and M. Ranjbar, 2017. Preparation of $\mathrm{AgO}_{2} / \mathrm{GrO}$ nanocomposites by hydrothermal method and investigation of photoluminescence properties. J. Mater. Sci. Electron., 28: 3185-3190. 
Muzamil, M., N. Khalid, M.D. Aziz and S.A. Abbas, 2014. Synthesis of silver nanoparticles by silver salt reduction and its characterization. IOP. Conf. Ser. Mater. Sci. Eng., 60: 012034-012041.

Nwanya, A.C., P.E. Ugwuoke, B.A. Ezekoye, R.U. Osuji and F.I. Ezema, 2013. Structural and optical properties of chemical bath deposited silver oxide thin films: Role of deposition time. Adv. Mater. Sci. Eng., 2013: $1-8$.

Saez, V. and T.J. Mason, 2009. Sonoelectrochemical synthesis of nanoparticles. Molecules, 14: 4284-4299.
Silva, J.N., J. Saade, P.M. Farias and E.H.L. Falcao, 2013. Colloidal synthesis of silver nanoprisms in aqueous medium: influence of chemical compounds in UV/Vis absorption spectra. Adv. Nanoparticles, 2: 217-222.

Singho, N.D., N.A.C. Lah, M.R. Johan and R. Ahmad, 2012. FTIR studies on silver-poly (methylmethacrylate) nanocomposites via in-situ polymerization technique. Intl. J. Electrochem. Sci., 7: 5596-5603.

Sopousek, J., J. Bursik, J. Zalesak and Z. Pesina, 2012. Silver nanoparticles sintering at low temperature on a copper substrate: In situ characterization under inert atmosphere and air. J. Min. Metall., Sect. B. Metall., 48: 63-71. 